\title{
Retrospective evaluation of the correlation between climatic factors and peripheral vertigo
}

\section{İklimsel faktörlerin periferik vertigo ile ilişkisinin retrospektif analizi}

\author{
Adem Bora ${ }^{1}$, Kasım Durmuşs ${ }^{1}$, Selim Çam² ${ }^{2}$ Emine Elif Altuntaș ${ }^{1}$
}

Sivas Cumhuriyet Üniversitesi Tıp Fakültesi, KBB Hastalıkları Anabilim Dalı, Sivas/Türkiye

${ }^{2}$ Sivas Cumhuriyet Üniversitesi Araştırma ve Uygulama Hastanesi, İstatistik Birimi, Sivas, Türkiye

Corresponding author: Adem Bora, MD, Sivas Cumhuriyet Üniversitesi Tıp Fakültesi, KBB Hastalıklanı Anabilim Dalı, Sivas, Türkiye

E-mail: adembora2016@gmail.com

Received/Accepted: May 11, 2019 /June 25, 2019

Conflict of interest: There is not a conflict of interest.

\begin{abstract}
SUMMARY
Objective: The present study was to examine the seasonal distribution of vertigo and to retrospectively investigate the correlations between vertigo and climatic variables in a region, where the continental climate is dominant.

Method: Fifty-two cases, who applied to our clinic with the complaint of vertigo in between July 2015 and June 2017 and were diagnosed with peripheral vertigo, were included in the study. Meteorological parameters were obtained from YYY weather station.

Results: When examining the distribution of the cases by seasons; it was determined that although the number of cases increased in the autumn months. A statistically significant correlation also was not determined between seasonal parameters evaluated and vertigo $(p>0.05)$. When regression analysis individually was performed in terms of causality between climatic parameters and vertigo, the causality in all variables, except for the minimum air temperature during the period of evaluation, was found to be significant. When the difference between sudden short term changes in seasonal variables and the values identified on the day of the episode was evaluated, there was a statistically significant difference for all parameters of evaluation except for precipitation $(p<0.05)$.

Conclusions: The results of the study revealed that the number of cases increased in the months when seasonal changes with distinct differences in temperature occurred. The results of the related studies in the literature are different from each other. Therefore, we have concluded that it is possible to evaluate clearly the correlation between climatic parameters and vertigo only with studies involving different climatic regions.
\end{abstract}

Keywords: Season, weather, peripheral vertigo, causality

\section{ÖZET}

Amaç: Bu çalışmada karasal iklimin hakim olduğu bir bölgede baş dönmesinin mevsimsel dağılımını ve iklim değişkenleriyle olan korelasyonlarını retrospektif olarak araştırılması amaçlanmıştır

Yöntem: Bu çalışma Temmuz 2015-Haziran2017 yılları arasında periferik vertigo tanısı alan 52 olgu dahil edildi. Hastaların tanı ve tedavi dönemlerine ait meteorolojik parametrelere Sivas Meteoroloji istasyonundan ulaşıldı.

Bulgular: Çalışmada yer alan olguların aylara göre dağılımına bakıldığında hemen hemen her ayda vertigo tanılı olgu ile karşılaşıldığı görüldü. Mevsimlere göre olguların dağılımına bakıldığında sonbahar aylarında olgu sayısında artış olduğu izlenmekle birlikte istatistiksel açıdan anlamlı bir ilişki saptanmadı ( $>>0.05 ; p=0.230)$. Değerlendirilen iklimsel parametreler ile vertigo arasında da istatistiksel açıdan anlamlı bir ilişki saptanmadı $(\mathrm{p}>0.05)$. İklimsel parametreler ile 
vertigo arasındaki nedensellik açısından tek tek regresyon analizi yapıldığında değerlendirme yapılan periyodda ki minimum hava sıcaklığı dışında tüm değişkenlerde nedensellik anlamlı bulundu. İklimsel değişkenlerde yaşanan ani kısa dönem değişiklikler ile atağın olduğu günde tespit edilen değerleri arasındaki fark değerlendirildiğinde yağış miktarı dışında tüm değerlendirme parametrelerinde istatistiksel açıdan anlamlı bir farklılık söz konusu idi $(\mathrm{p}<0.05)$.

Sonuç: Sonuçlarımız sıcaklıkta belirgin değişim olan mevsim dönüşlerinin yaşandığı aylarda olguların arttığını ancak istatistiksel olarak mevsim ile vertigo arasında anlamlı bir ilişki olmadığını göstermektedir. Literatürde bu konuda yapılmış olan çalışmaların sonuçları birbirlerinden farklılıklar göstermektedir. Bu nedenle iklimsel parametreler ve vertigo arasındaki ilişkinin net olarak değerlendirilmesinin ancak farklı iklim bölgelerini içeren çalışmalar ile mümkün olacağı kanısındayız.

Anahtar sözcükler: Mevsim, hava durumu, periferik vertigo, nedensellik

\section{INTRODUCTION}

Vertigo is a symptom occurring by stimulation or dysfunctions of the vestibular system. Vertigo and dizziness is a problem that influences approximately $20-40 \%$ of the general population ${ }^{1}$. Vertigo and dizziness may occur with nonvestibular reasons based on vestibular disorders such as benign paroxysmal positional vertigo (BPPV) or Meniere's disease; cardiovascular diseases, hypertension, psychiatric disorders or side effects of various drugs ${ }^{2}$.

Studies investigating the correlation between vertigo, associated with peripheral vestibular pathologies in which numerous factors play a role in the etiology, and environmental factors such as climatic conditions and air pollution have been remarkable in recent years ${ }^{3-10}$. However, pathophysiological mechanisms underlying the seasonal distribution of dizziness have still remained uncertain. Since climatic variables can't be controlled experimentally, seasonal variables observed in every season such as humidity, precipitation, temperature, etc., would have different effects on vertigo.

By considering the results of a limited number of studies conducted on this issue in the literature, the present study was aimed to investigate the retrospectively seasonal distribution of vertigo and the correlations between vertigo and climatic variables in a region, where the continental climate is dominant, such as YYYY.

\section{MATERIAL AND METHODS}

The present study included 52 cases who applied to otorhinolaryngology Outpatient clinic of Cumhuriyet University between July 2015 and June 2017 due to the complaint of vertigo and were diagnosed with peripheral vertigo via history, physical examination, audiological examination, and positional tests and whose files were accessed from the archive of our hospital.

Signed consents of all the cases included in the study were obtained, and those who agreed to participate in the study were included in the study.
Approval was taken from Cumhuriyet University Clinical Trials Ethics Committee, and the study was conducted in accordance with the Declaration of Helsinki.

Cases with findings in their history, suggesting central vertigo and whose neurological evaluation supported this diagnosis were excluded from the study. All cases who were identified to have symptoms compatible with peripheral vertigo in their history were subject to detailed Ear Nose Throat (ENT) and systemic examinations. The cases identified with pathology in tympanum and/or middle ear after ENT examination were excluded from the study. Spontaneous nystagmus examination, walking examination, cerebellar tests, and neurological examination was performed in the systemic examination; the cases whose examination results suggested neurological disease were excluded from the study.

All cases whose examination results indicated peripheral pathology were assessed from pure sound audiometry, distinguishing speaking and thresholds of receiving, and tympanometric evaluation. As a result of these evaluations, cases with results of hearing loss and pathological tympanometry indicating interior ear or middle ear pathology were excluded from the study.

Complete blood count, biochemical evaluation, vitamin $\mathrm{B} 12$, and folic acid values are routinely asked in our clinic for the cases, who are thought to have peripheral vertigo, in order to eliminate metabolic disorders that may lead to vertigo. Cases, who were identified to have pathology as a result of these examinations, were excluded from the study.

Individuals, who had typical symptoms for peripheral vertigo; complaints of spinning short term dizziness, which is triggered by head movements, nausea, and vomiting; and no other neurological and otologic pathology, were included in the study.

The Dix-Halpike maneuver was performed in all of the cases. cVEMP (Cervical vestibular evoked myogenic potentials) (Otometrics ICS Chartr EP 
200; Denmark)was also applied to all the cases which could show compliance to the test or did not have contraindication (neck problems etc.) for the test.

Meteorological data, including mean monthly temperature, relative humidity, atmospheric pressure, precipitation, and maximum and minimum temperatures, were used for evaluation. Three-year climatic and environmental data by the days between 2015 and 2017 belonging to diagnosis and treatment periods of the cases were obtained from YYYY Directorate of Meteorology. In order to investigate the correlations between climatic and basic environmental data and peripheral vertigo, meteorological values obtained 10 days before the onset of the disease (based on the day when patient's complaints were started) and in a 21-day period after the start of the treatment were used.

Every year was divided into four seasons as spring (March 1-May 31), summer (June 1-August 31), autumn (September 1-November 30), and winter (December 1-February 28/29) in order to evaluate the seasonal distribution of peripheral vertigo.

It was also paid attention for the cases to reside in the city center or districts of YYY to ensure that they were exposed to homogenous environmental factors in terms of similar climatic and environmental conditions.

Statistical Analysis
The data were analyzed using the Statistical Package of Social Science (SPSS Inc., Chicago, IL) for Windows version 23.0. The data were assessed by using chi-square test, dependent samples t-test (Paired Sample t-Test), and Pearson's correlation test. Simple linear regression analyses were interpreted at $95 \%$ of confidence level. One-Sample t-Test was used to investigate whether or not climatic data had differences in the recent period. Level of significance was taken as 0.05 .

\section{RESULTS}

The average age of 52 cases who applied to our clinic due to complaint of vertigo and were diagnosed with peripheral vertigo via clinics, history, examination, and Dix-Halpike maneuver was $50.23 \pm 12.92$ years $(\min / \max : 13-76$ years), the average age of the male patients was $51.74 \pm 9.41$ years ( $\mathrm{min} / \max : 33-73$ years), the average age of the female patients was $49.03 \pm$ 15.20 years (min/max: $13-76$ years).

When the distribution of the cases included in the study based on months and gender was examined, it was observed that there were cases diagnosed with vertigo almost in every month; $55.8 \%(\mathrm{n}=29)$ of the cases were female, and $44.2 \%(n=23)$ of the cases were male (Graphic 1). Graphic 2 showed the distribution of cases when the whole study period was divided into months. Accordingly, the number of cases were observed to increase in August, September, and November.

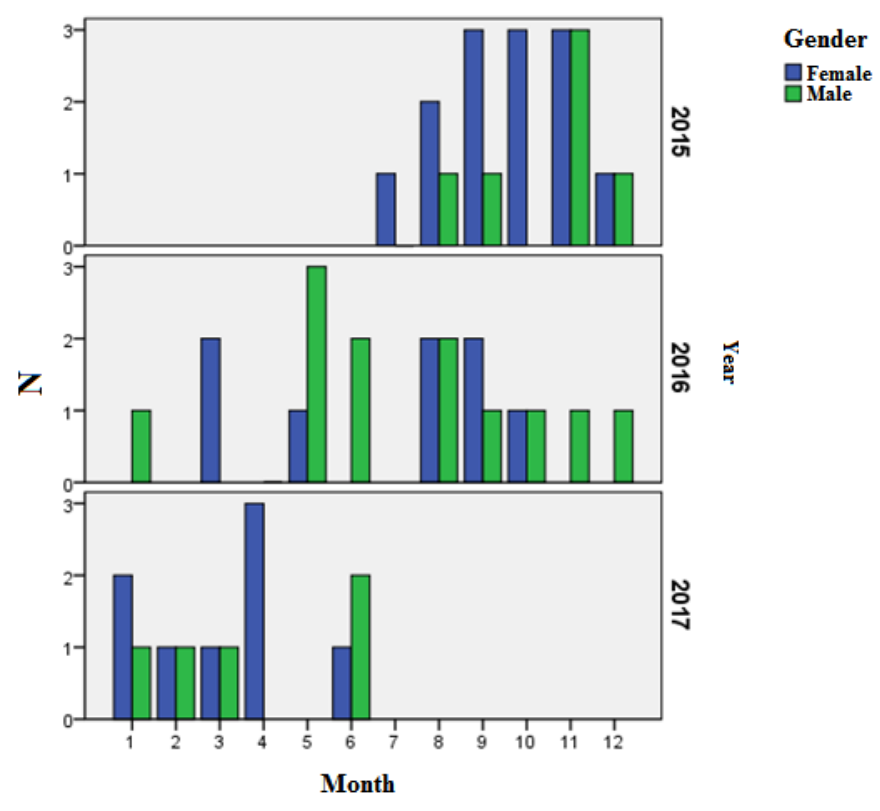

Graphic 1: Distribution of the cases by months and gender 


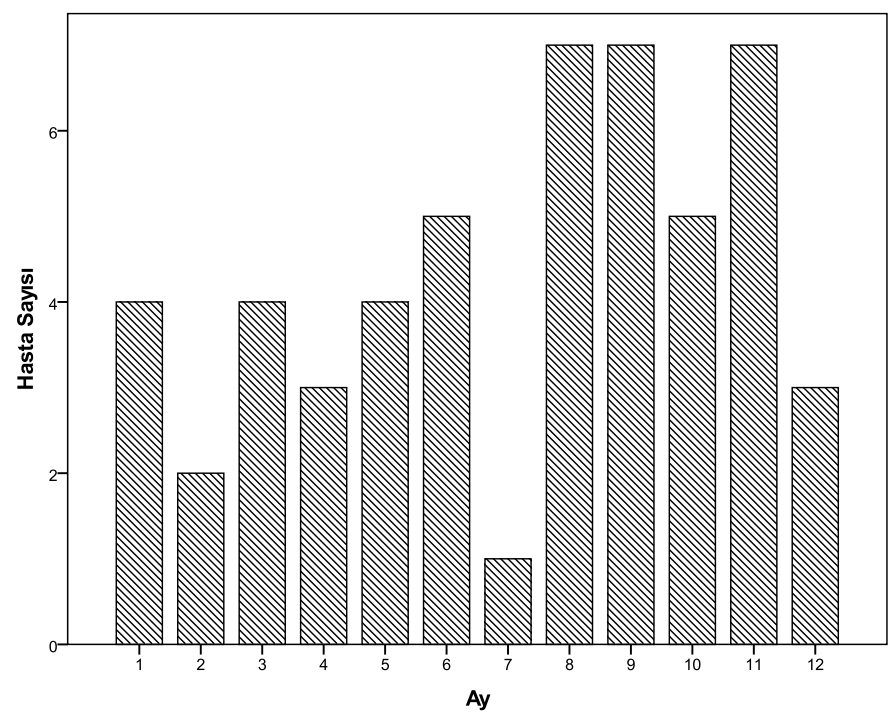

Graphic 2: Distribution of the cases as the whole study period was divided into months

Nystagmus was identified in $86.5 \%(n=45)$ of the cases with peripheral vertigo; direction of nystagmus was rightward for $53.3 \%(\mathrm{n}=24)$ and leftward for $46.7 \%(\mathrm{n}=21)$. Nystagmus identified in the cases was horizontal in $60 \%(\mathrm{n}=27)$ and horizontal-rotatory in $40 \%(\mathrm{n}=18) .85 .5 \%(\mathrm{n}=46)$ of the cases had complaint of nausea and $46.2 \%$ $(\mathrm{n}=24)$ had vomiting.

As the cases were evaluated in terms of the number of vertigo episodes experienced within a year, $32.7 \%(\mathrm{n}=17)$ had the history of episode once a year, $13.5 \%(\mathrm{n}=7)$ twice a year, and $53.8 \%(\mathrm{n}=28)$ three times or more a year. There was no statistical correlation between episode frequency of the patients and seasons ( $p>0.05)$.

When examining distribution of cases with peripheral vertigo by seasons; it was determined that $17.31 \%\left(\mathrm{n}_{\text {Winter }}=9\right)$ in the winter months, $21.15 \%\left(\mathrm{n}_{\text {Spring }}=11\right)$ in the spring months, $25 \%$ $\left(\mathrm{n}_{\text {Summer }}=25\right)$ in the summer months, and $36.54 \%$ $\left(a_{\text {utumn }}=19\right)$ in the autumn months were followed up, respectively. When the distribution of the cases was evaluated by seasons, it was determined that although the number of cases increased in the autumn months, there was no statistically significant correlation $(\mathrm{p}>0.05 ; \mathrm{p}=0.230)$.

Table 1 summarizes meteorological parameters obtained 10 days before the onset of symptoms and in a 21-day period after the start of the treatment based on the onset day of complaints of cases with peripheral vertigo. As indicated in the table, there was no statistically significant difference between meteorological parameters obtained in the 10-day period before the onset of symptoms and in the 21-day period after the start of the treatment $(\mathrm{p}>0.05)$. A statistically significant correlation was not also determined between climatic parameters evaluated in the study and vertigo ( $p>0.05)$. However, climatic parameters were observed to have a significant correlation with each other $(\mathrm{p}<0.05)$ (Table 2). Because there was a correlation between climatic variables, it was impossible to estimate the number of patients by including all climatic variables in the model. Estimation of the number of patients by using climatic characteristics individually was possible with simple linear regression analysis. In Table $\mathbf{3}$, the causality relationship was found to be significant in all variables except for the variable of minimum temperature in the analyses performed using a total of 7 models. However, when the regression analysis was individually performed in terms of the causality between climatic parameters and vertigo, the causality was found to be significant all variables in the 31-day period evaluated except for minimum temperature (Table 3).

When assessing the difference between sudden short term changes (5 days before episode) experienced in climatic variables and values determined on the day of episode, there was a statistically significant difference in all parameters except for precipitation $(\mathbf{p}<\mathbf{0 . 0 5})($ Table 4). 
Table 1: Mean value of every meteorological parameter obtained 10 days before the onset of symptoms and in the 21-day period after the start of the medical treatment

\begin{tabular}{|c|c|c|c|c|c|}
\hline \multicolumn{2}{|c|}{ Meteorological Parameters } & Mean \pm SD & Minimum & Maximum & P value \\
\hline \multirow{2}{*}{$T_{\min }\left({ }^{0} \mathrm{C}\right)$} & Before & $4.518 \pm 8.261$ & -11.540 & 16.390 & \multirow[t]{2}{*}{0.587} \\
\hline & After & $4.274 \pm 7.907$ & -10.095 & 16.715 & \\
\hline \multirow[t]{2}{*}{$\left.T_{\max }{ }^{0} \mathrm{C}\right)$} & Before & $17.893 \pm 10.868$ & -4.400 & 34.150 & \multirow[t]{2}{*}{0.556} \\
\hline & After & $17.537 \pm 10.606$ & -2.355 & 33.035 & \\
\hline \multirow[t]{2}{*}{$T_{\text {mean }}\left({ }^{\circ} \mathrm{C}\right)$} & Before & $10.535 \pm 9.472$ & -8.330 & 24.200 & \multirow[t]{2}{*}{0.615} \\
\hline & After & $10.291 \pm 9.225$ & -6.500 & 24.295 & \\
\hline \multirow[t]{2}{*}{$R H$} & Before & $60.574 \pm 10.735$ & 39.930 & 79.240 & \multirow[t]{2}{*}{0.924} \\
\hline & After & $60.683 \pm 10.876$ & 41.683 & 78.840 & \\
\hline \multirow[t]{2}{*}{$R f$} & Before & $1.122 \pm 1.402$ & .000 & 5.730 & \multirow[t]{2}{*}{0.384} \\
\hline & After & $.974 \pm 1.134$ & .000 & 4.815 & \\
\hline \multirow[t]{2}{*}{$P_{\operatorname{Min}}$} & Before & $871.003 \pm 2.423$ & 866.310 & 877.280 & \multirow[t]{2}{*}{0.274} \\
\hline & After & $871.389 \pm 2.596$ & 866.430 & 878.560 & \\
\hline \multirow[t]{2}{*}{$P_{\operatorname{Max}}$} & Before & $874.513 \pm 2.574$ & 868.980 & 880.680 & \multirow[t]{2}{*}{0.171} \\
\hline & After & $874.938 \pm 2.585$ & 871.040 & 881.280 & \\
\hline \multirow[t]{2}{*}{$P_{\text {Mean }}$} & Before & $872.916 \pm 2.446$ & 867.890 & 879.190 & \multirow[t]{2}{*}{0.210} \\
\hline & After & $873.329 \pm 2.519$ & 869.200 & 879.995 & \\
\hline \multicolumn{6}{|c|}{$\begin{array}{l}T_{\max } ; \text { Maximum Temperature, } T_{\min } ; \text { Minimum Temperature, } T_{\text {mean }} \text {, Mean Temperature, } R H \text {; Relative } \\
\text { humidity, } R f ; \text { Precipitation, } P_{\text {Min }} ; \text { Minimum Atmospheric Pressure, } P_{\text {Max }} ; \text { Maximum Atmospheric } \\
\text { Pressure, } P_{\text {Mean }} ; \text { Mean Atmospheric Pressure }\end{array}$} \\
\hline
\end{tabular}

Table 2: The correlation analysis based on the number of patients

\begin{tabular}{|l|l|l|l|l|l|l|l|l|}
\hline & & $\begin{array}{l}T_{\min } \\
\left({ }^{\circ} \mathrm{C}\right)\end{array}$ & $\left.T_{\max }{ }^{\circ} \mathrm{C}\right)$ & $R H$ & $\mathrm{Rf}$ & $P_{\text {Min }}$ & $P_{\text {Max }}$ & $P_{\text {Mean }}$ \\
\hline $\begin{array}{l}\text { Number } \\
\text { patients }\end{array}$ & $\mathrm{r}$ & .285 & .342 & -.428 & -.306 & .237 & .156 & .216 \\
\cline { 2 - 10 } & $\mathrm{p}$ & .185 & .138 & .083 & .166 & .229 & .314 & .250 \\
\hline
\end{tabular}

$T_{\max } ;$ Maximum Temperature, $T_{m i n}$ : Minimum Temperature, $T_{\text {mean }}$ : Mean Temperature, $R H$; Relative humidity, $R f$; Precipitation, $P_{M i n}$; Minimum Atmospheric Pressure, $P_{M a x}$; Maximum Atmospheric Pressure, $P_{\text {Mean }} ;$ Mean Atmospheric Pressure

Table 3: Simple linear regression models of climatic characteristics based on the number of patients

\begin{tabular}{|l|l|l|l|l|l|}
\hline & $\begin{array}{l}\text { Independent } \\
\text { Variable }\end{array}$ & $\boldsymbol{\beta}$ & Significance & $\begin{array}{l}\text { Standard } \\
\text { Deviation }\end{array}$ & $\mathbf{R}^{\mathbf{2}}$ \\
\hline Model 1 & $T_{\max }\left({ }^{\circ} \mathrm{C}\right)$ & 0.207 & $<0.001$ & 2.52 & 0.715 \\
\hline Model 2 & $T_{\operatorname{mean}}\left({ }^{\circ} \mathrm{C}\right.$ & 0.278 & 0.002 & 3.15 & 0.556 \\
\hline Model 3 & $\mathrm{RH}$ & 0.067 & $<0.001$ & 2.36 & 0.75 \\
\hline Model 4 & $\mathrm{Rf}$ & 2.078 & 0.02 & 3.82 & 0.348 \\
\hline Model 5 & $P_{\text {Min }}$ & 0.005 & $<0.001$ & 1.97 & 0.827 \\
\hline Model 6 & $P_{\text {Max }}$ & 0.005 & $<0.001$ & 1.97 & 0.827 \\
\hline Model 7 & $P_{\text {Mean }}$ & 0.005 & $<0.001$ & 1.97 & 0.827 \\
\hline
\end{tabular}

$T_{\text {max }}$; Maximum Temperature, $T_{\min }$; Minimum Temperature, $T_{\text {mean }}$ : Mean Temperature, $R H$; Relative humidity, $R f$; Precipitation, $P_{\text {Min }}$; Minimum Atmospheric Pressure, $P_{\text {Max }}$; Maximum Atmospheric Pressure, $P_{\text {Mean }}$; Mean Atmospheric Pressure 
Table 4: Mean values of climatic variables monitored and evaluated on the day of the episode

\begin{tabular}{|l|l|l|l|l|}
\hline $\begin{array}{l}\text { Meteorological } \\
\text { Parameters }\end{array}$ & Mean \pm SD & Minimum & Maximum & P value \\
\hline$T_{\min }\left({ }^{\circ} \mathrm{C}\right)$ & $0.82 \pm 5.73$ & -9.70 & 14.20 & \\
\hline$\left.T_{\max }{ }^{\circ} \mathrm{C}\right)$ & $-0.88 \pm 4.83$ & -10.60 & 10.10 & $<0.001$ \\
\hline$T_{\operatorname{mean}}\left({ }^{\circ} \mathrm{C}\right)$ & $0.07 \pm 4.59$ & -9.80 & 11.30 & $<0.001$ \\
\hline$R H$ & $1.14 \pm 12.96$ & -40.70 & 38.80 & $<0.001$ \\
\hline$R f$ & $0.37 \pm 4.02$ & -12.30 & 20.10 & 0.110 \\
\hline$P_{\text {Min }}$ & $-0.83 \pm 4.52$ & -14.60 & 10.60 & $<0.001$ \\
\hline$P_{\text {Max }}$ & $-1.01 \pm 4.39$ & -9.50 & 11.70 & $<0.001$ \\
\hline$P_{\text {Mean }}$ & $-0.89 \pm 4.34$ & -10.80 & 11.80 & $<0.001$ \\
\hline
\end{tabular}

$T_{\max }$; Maximum Temperature, $T_{\min }$ : Minimum Temperature, $T_{\text {mean }}$ : Mean Temperature, $R H$; Relative humidity, $R f$; Precipitation, $P_{\text {Min }}$; Minimum Atmospheric Pressure, $P_{\text {Max }}$; Maximum Atmospheric Pressure, $P_{\text {Mean }}$; Mean Atmospheric Pressure

\section{DISCUSSION}

When considering the results obtained from the present study, it was observed that there was no correlation between the number of patients diagnosed with vertigo and climatic characteristics; however, there was a unidirectional causality between them. The results obtained from causality evaluation would help researchers in related studies to be conducted in our region for estimating how many patients with vertigo would be followed up in which season by climatic variables. The obtained results indicate that the increases in precipitation, humidity, pressure, maximum, and mean temperature may lead to an increased incidence in patients with vertigo. Evaluation with annual climatic variables was observed to be different when assessing the difference between sudden short term changes (5 days before episode) experienced in climatic variables and values determined on the day of episode. Accordingly, it was concluded that the number of cases with vertigo should be expected to increase if sudden changes such as increase or decrease occur in climatic variables.

Various studies revealed that existing diseases or current health conditions of individuals might be influenced by atmospheric conditions, and some people were more susceptible to weather condition compared to others. In a study conducted in Canada and Germany independently, vertigo was observed at a high rate such as $26 \%$ among the symptoms followed in relation to weather conditions in Germany ${ }^{3}$.

There are several studies emphasizing that there might be a correlation between vertigo and seasons. However, pathophysiological mechanisms underlying this correlation have still remained uncertain. Therefore, it should not be ignored that studies investigating epidemiological and risk factors about vertigo and dizziness may help developing new hypotheses and alternative treatment methods regarding pathophysiology ${ }^{11}$ 12 .

A 3-year period retrospective study conducted by Çağlar et al.,(4) on 245 patients with BPPV in 2013 pointed out that the number of patients increased particularly in the winter months. The same study also revealed that there was a statistically significant negative correlation between the number of patients and temperature. Similarly, in the study conducted by Mariani et al., ${ }^{[5]}$ in 2008 on 575 cases, they showed that there was a negative correlation between weather temperature and the disease and the frequency of episodes was associated with changes of temperature. Differently, from these studies, the present study indicated that sudden changes in temperature led to the occurrence of cases with vertigo rather in increasing number. However, it was thought that this difference was associated with the fact that YYY province already has a cold continental climate, and annual mean temperature is about $3 \mathrm{C}^{0}$ and lower.

Whitman and Baloh ${ }^{6}$ compared the number of cases diagnosed with BPPV in March, April, and May and the number of the cases in the remaining months of the year in a hospital in Boston in order to reveal the correlation of BPPV both with seasons and vitamin D deficiency and showed that the number of cases was higher in the spring months than the other months of the year for a 5year period. However, they stated in their study that it would not right to associate this directly with vitamin $\mathrm{D}$ deficiency monitored in individuals during these months. 
Various studies reported that there might be the unequal seasonal distribution for vertigo, Meniere's disease, and paroxysmal vestibular vertigo; however, they were monitored more frequently in spring and winter months $7,13,14$. Pereira et al., ${ }^{9}$ investigated seasonal distribution of cases with vertigo and dizziness in a tropical region and the correlation to climatic variables in their study and they revealed that there was a significant correlation between vertigo and dizziness and seasons. The present study concluded that vertigo was rather observed in winter and late spring, showed a negative correlation with humidity $(r=-0.374 ; p=0.013)$ and precipitation $(\mathrm{r}=-0.334 ; \mathrm{p}=0.020)$. Even though there are the studies also from Italy and Taiwan besides the study of Pereira et al., (9) supporting that vertigo was observed more frequently in winter-spring, the presence of studies indicating that there was a peak for vestibular neuronitis in the summer in Pakistan and there was no correlation between vestibular diseases and seasons in Brazil should not be ignored $^{5,13,15,16}$. Thus, there are distinct decreases of temperature in the months when seasonal transitions are observed since YYYY province is in continental climate zone. Accordingly, it was observed that the number of cases increased dramatically although it was not statistically significant in the present study in the months when seasonal transitions occur (August, etc.). Since most of the above-mentioned studies were conducted in different climatic zones, we concluded that this was associated with the reason for the difference between the results.

Today, there are numerous hypotheses suggested explaining the reason why cases with vertigo are seen rather in the spring and winter months. The fundamental reference point of many of these is that increased upper respiratory infections seen more frequently in these seasons, and allergic diseases can trigger the development of vertigo symptom by influencing inner ear ${ }^{17-19}$. However, there have been no studies with a high level of evidence verifying these hypotheses.

Another speculative hypothesis suggested to explain the correlation between vertigo, and climatic factors are that warm or arid climate conditions lead to vertigo by influencing systemic fluid and electrolyte balance and causing fluid involvement in the inner ear through the release of natriuretic peptides - imbalanced fluid in labyrinth results in episodes of vertigo in Meniere's disease ${ }^{20}$.
Gürkov et al., ${ }^{21}$ investigated whether or not there was a correlation between vertigo episodes seen in Meniere's disorder and atmospheric pressure. Results of their study pointed out that there might be a significant correlation between the change of atmospheric pressure and the onset of episodes. Change of mean pressure, especially on the day just before episodes of patients was found to be significant.

In their study, Schmidt et al., ${ }^{10}$ examined the correlation between atmospheric pressure and Meniere's disease, and they pointed out that atmospheric pressure and humidity variations had an effect on the exacerbation of symptoms. The results of their study indicated that low daily atmospheric pressure caused the complaints of tinnitus and aural fullness as well as increased episodes of vertigo in the patients. When atmospheric pressure was below $1013.25 \mathrm{hPa}$, episodes of cases were determined to be observed at a rate of $23 \%$ more. In addition, the results of this study indicated that there were 1.56 times (95\% CI 1.23, 1.96) greater risk for an episode on the days with low pressure and high humidity compared to days with high pressure and low humidity. Likewise this study, Pereira et al. ${ }^{9}$ stated in their study that there was a negative correlation between atmospheric pressure and not only patients with Meniere's disease but also patients applying to the emergency room with complaints of vertigo. The result obtained related to changes in pressure in the present study were similar to those of the study by Pereira et al., ${ }^{9}$. Changes of pressure were rather negative in the pre-episode period and on the day of the episode, which made us think that there might be a correlation between low pressure and episodes.

Although in the literature some studies conducted to reveal the correlation between season and vertigo point out there is an increase for the number of cases with peripheral vertigo during winter and cold weather, there are also studies not supporting these results. In conclusion, it would be more appropriate to evaluate cases with vertigo locally based on geographical and climatic characteristics of the region, where the study was conducted, and not to make a generalization about this issue.

Results of the present study indicate that the number of cases increased in months of seasonal transformations during which there are distinct temperature changes; however, there was no statistically significant correlation between season and vertigo. But, when evaluation parameters at the moment of the episode were compared with 
values obtained in a short period earlier, there might be a correlation between episode and all climatic factors except for precipitation.

However, we know that there are some limitations to our study. These limitations include; a) Low number of cases, b) No investigation has been conducted to assess the pathophysiology of the relationship between vertigo and seasons, c) May be associated with vertigo; serum vitamin D level or systemic fluid-electrolyte balance not investigated, d) The fact that the evaluated cases were evaluated according to the general average of the meteorological parameters obtained in Sivas, not in the specific place of residence.

\section{CONCLUSION}

As is understood from the literature review and the present study conducted in YYY province, it is thought that sudden climatic changes (increase and/or decrease) are the factors to increase the vertigo episode in people adapted to local life conditions. Sudden declines of temperature in temperate climates with a high rate of precipitation such as Germany, Brazil, and England; sudden increases of temperature in cold and continental climates like YYYY are effective in the development of vertigo episode. Therefore, we would like to draw attention on the result that studies need to be planned by considering the possibility that there might be a temperature range triggering the development of vertigo episode rather than having a definite conclusion about the correlation between vertigo and climatic factors.

Consequently, it is thought that precise evaluation of the correlation between seasonal factors and vertigo is possible only with studies that are crosssectional and multi-centered and include different climatic zones. We also believe that increasing the number of cases will provide more reliable results.

\section{REFERENCES}

1.Bittar RSM, Oiticica J, Bottino MA, et al. Population epidemiological study on the prevalence of dizziness in the city of Sa o Paulo. Braz J Otorhinolaryngol 2013; 79: 688-98.

2.Mueller M, Strobl R, Jahn K, Linkohr B, Peters A, Grill E. Burden of disability attributable to vertigo and dizziness in the aged: results from the KORA-Age study. Eur J Public Health. 2014; 24(5): 802-7.

3.von Mackensen S, Hoeppe $P$, Maarouf A, Tourigny P, Nowak D. Prevalence of weather sensitivity in Germany and Canada. Int $\mathrm{J}$ Biometeorol 2005; 49: 156-66.
4.Çağlar E, Çelebi Ş, Karaca TÇ, Çelik Ö. Bening Paroksismal Pozisyonel Vertigonun Çevresel ve İklimsel Faktörler ile İlişkisi. Turk Arch Otolaryngol 2013; 51: 74-9.

5.Mariani P, Pelagatti M, Hahn A, Alpini D. Epidemiology of paroxysmal positioning vertigo: correlation with seasons, climate, and pollution. Int Tinnitus J 2008; 14: 168-74.

6.Whitman GT, Baloh RW. Seasonality of Benign Paroxysmal Positional Vertigo. JAMA Otolaryngology-Head \& Neck Surgery. 2015; 141(2):188-189.

7.Celestino D, Ralli G, Merolla A, et al. Seasonal recurrence of acute episodes of Meniere's disease. Acta Otorhinolaryngol Belg 1987; 41: 951-7.

8.Meghji S, Murphy D, Nunney I, Phillips JS. The Seasonal Variation of Benign Paroxysmal Positional Vertigo. Otol Neurotol. 2017; 38(9): 1315-1318.

9.Pereira AB, Almeida LA, Pereira NG, Menezes PA, Felipe L, Volpe FM. Seasonality of dizziness and vertigo in a tropical region. Chronobiol Int. 2015; 32(5): 585-90.

10.Schmidt W, Sarran C, Ronan N, Barrett G, Whinney DJ, Fleming LE, Osborne NJ, Tyrrell J. The Weather and Ménière's Disease: A Longitudinal Analysis in the UK. Otol Neurotol. 2017; 38(2): 225-233.

11.Neuhauser HK. Epidemiology of vertigo. Curr Opin Neurol. 2007; 20(1): 40-6. Review.

12.Neuhauser HK. The epidemiology of dizziness and vertigo. Handb Clin Neurol. 2016; 137: 6782. Review.

13.Lai YT, Wang TC, Chuang LJ, et al. Epidemiology of vertigo: A National Survey. Otolaryngol Head Neck Surg 2011; 145: 110-16.

14.Wladislavosky-Waserman P, Facer GW, Mokri B, Kurland LT. Meniere's disease: A 30-year epidemiologic and clinical study in Rochester, Mn, 1951-1980. Laryngoscope 1984; 94: 1098102.

15.Siddiqui IA, Kalwar AW, Dogar MR, Rafi SMT. Epidemiology of vestibular neurinitis in vertigo presenting at tertiary care health care facility in Pakistan. Pak J Med Sci 2011; 27: 4279.

16.Bilecki MM, Bernarde GE, Mezzalira R, Maestri JE, Cardoso JM, Avila FG. Seasonality in vestibular disorders. Int Tinnitus J 2005; 11(2): $185-8$. 
17.Neffen H, Mello JF Jr, Sole D, Naspitz CK, Dodero AE, Garza HL, Guerra EN, Baez-Loyola C, Boyle JM, Wingertzahn MA. Nasal allergies in the Latin American population: results from the Allergies in Latin America survey. Allergy Asthma Proc 2010; 31 Suppl 1: S9-27.

18.Saha S, Chadha M, Al Mamun A, Rahman M, Sturm-Ramirez K, Chittaganpitch M, Pattamadilok S, Olsen SJ, Sampurno OD, Setiawaty V, Pangesti KN, Samaan G, Archkhawongs S, Vongphrachanh P, Phonekeo D, Corwin A, Touch S, Buchy P, Chea N, Kitsutani $\mathrm{P}$, Mai le Q, Thiem VD, Lin R, Low C, Kheong CC, Ismail N, Yusof MA, Tandoc A 3rd, Roque V Jr, Mishra A, Moen AC, Widdowson MA, Partridge J, Lal RB. Influenza seasonality and vaccination timing in tropical and subtropical areas of southern and south-eastern Asia. Bull World Health Organ 2014; 92(5): 318-30.
19.Tamerius J, Nelson MI, Zhou SZ, Viboud C, Miller MA, Alonso WJ. Global influenza seasonality: reconciling patterns across temperate and tropical regions. Environ Health Perspect 2011; 119(4): 439-45. Review.

20.Gürkov R, Flatz W, Louza J, Strupp M, ErtlWagner B, Krause E. In vivovisualized endolymphatic hydrops and inner ear functions in patients with electrocochleographically confirmed Ménière's disease. Otol Neurotol 2012; 33(6): 1040-5.

21.Gürkov R, Strobl R, Heinlin N, Krause E, Olzowy B, Koppe C, Grill E. Atmospheric Pressure and Onset of Episodes of Menière's Disease - A Repeated Measures Study. PLoS One 2016; 11(4): e0152714. 